\title{
ADVANCES IN PARASITOLOGY
}

\section{Volume 12}

\author{
Organized and edited by \\ BEN DAWES \\ Professor Emeritus, University of London, England \\ October/November $1974 \quad x i i+432$ pp., f10.50/\$27.75 0.12 .031712 .5

\section{Contents}

A. Murray Fallis, Sherwin S. Desser and Rasul A. Khan : On species of Leucocytozoon. Wallace Peters: Recent advances in antimalarial chemotherapy and drug resistance. M. A. Stirewalt : Schistosoma mansoni : cercaria to schistosomule. D. F. Mettrick and R. B. Podesta : Ecological and physiological aspects of helminth-host interactions in the mammalian gastrointestinal canal. J. F. Michel: Arrested development of nematodes and some related phenomena. Short Review: Naftale Katz and J. Pellegrino: Experimental chemotherapy of schistosomiasis mansoni.

Author index. Subject index.

\section{From reviews of previous volumes}

'The publication of each successive volume of Advances in Parasitology is keenly anticipated by parasitologists throughout the world. These authoritative reviews, which have been edited by Professor Ben Dawes since the first volume was published in 1963 are widely acclaimed as outstanding contributions to the subject...

G. S. Nelson in Tropical Diseases Bulletin

'The volumes in this series are essential equipment for any establishment engaged in teaching parasitology or in research on any parasitological problem.'

M. G. Christie in The British Veterinary Journal

'There are certain reviews that one looks forward to receiving with special pleasure, and to the parasitologist this is exemplified par excellence by Ben Dawes's yearly pocket masterpiece Advances in Parasitology.' W. Peters in The British Medical Journal

\section{Previous volumes}

Volume 11, $x x+778 \mathrm{pp} ., £ 14.00 / \$ 39.50$

Volume 10, xviii +412 pp., $£ 7.00 / \$ 21.50$

Volume 9 , xiv +276 pp., $£ 5.00 / \$ 14.50$

Volume $8, x v i+314$ pp., $£ 6.00 / \$ 16.00$

Volume 7, xxii +414 pp., $£ 7.50 / \$ 20.00$

Volume $6, x x+416 \mathrm{pp} ., £ 7.50 / \$ 19.00$

Volume $5, x v i+320$ pp., $£ 6.00 / \$ 16.00$

Volume 4, xvi +408 pp., $£ 8.00 / \$ 18.50$

Volume 3, xviii + 316 pp., $£ 6.00 / \$ 15.00$

Volume 2, xvi $+332 \mathrm{pp}$., $£ 6.00 / \$ 15.00$

Volume 1, xvi + 348 pp., $f 6.00 / \$ 15.00$

\section{ACADEMIC PRESS}

\section{LONDON - NEW YORK · SAN FRANCISCO}

A Subsidiary of Harcourt Brace Jovanovich, Publishers

24-28 Oval Road London NW1 England

111 Fifth Avenue New York NY10003 USA

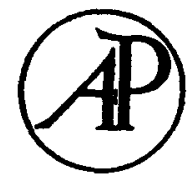




\section{Genetic Control of Insect Pests \\ G. DAVIDSON}

London School of Hygiene and Tropical Medicine, London, England

August 1974, $x+158$ pp., $\mathbf{f 4 . 0 0 / \$ 1 0 . 2 5}$

This is the first book to consider, together, all the genetic methods for controlling insect pests of agricultural, veterinary and medical importance, which have so far been developed to the point of practical application. As such it will be of the greatest interest to entomologists working in these fields, to doctors concerned with preventive medicine and to biologists and those with a more general interest in entomology and genetics.

Most of the methods considered involve the mass rearing of particular species, irradiation, chemosterilization or hybridization and then release into the wild population. Success depends on these insects mating with the wild populations, leading to reductions in fertility and perhaps to populations being eliminated. More involved techniques make use of naturally existing incompatibles, or introduce genes which are harmful to the wild population but favourable to man. The replacement of a naturally occurring population with one previously rendered harmless by genetic manipulation, is also discussed.

\section{Contents}

Introduction

The principles and dynamics involved in the sterile insect technique

Mass-rearing. Sterilization. Release. Dynamics. Sterilization by irradiation

Livestock pests. Agricultural pests. Public

health pests. Radiation resistance.

Chemosterilants

Public health pests. Agricultural pests.

Hybrid sterility

Anopheline mosquitoes. The Aedes mariae

complex. Tsetse fly crosses. Te/eogryllus

crosses. Reduviid bug crosses.

Cytoplasmic incompatibility

The Culex pipiens complex. The Aedes

scutellaris complex.

Translocations

General considerations. Dynamics. The isolation of translocations. Compound chromosomes.

Other methods of genetic control

Lethal factors. Meiotic drive and sex distortion.

Species replacement.

Summary and conclusion

References. Subject index.

\section{Academic Press London New York San Francisco}

A Subsidiary of Harcourt Brace Jovanovich, Publishers 24-28 Oval Road, London NW1, England

111 Fifth Avenue, New York, NY10003, USA 


\section{PARASITOLOGY}




\section{PARASITOLOGY}

(Founded by G.H.F. Nuttall, F.R.S.)

EDITORS

D. W. T. CROMPTON and B. A. NEWTON

EDITORIAL ASSISTANT

SANDRA K. RAY, M.A. Ph.D.

EDITORIAL BOARD

GWENDOLEN REES, F.R.S. (Chairman)
D. R. ARTHUR
D. L. LEE*
S. COHEN
J. LLEWELLYN
C. ELLENBY
W. F. MAI
L. G. GOODWIN
C. P. READ
C. A. HOPKINS
S. R. SMITHERS

P. TATE

* representing the British Society for Parasitology

PANEL OF REFEREES
C. ARME
D. I. GIBSON
M. ELAINE ROSE
R. A. AVERY
W. E. GUTTERIDGE
J. H. ROSE
J. R. BAKER
L. P. JOYNER
G. I. SHARPE
ELIZABETH U. CANNING
C. R. KENNEDY
G. SALT, F.R.S.
THERESA CLAY
R. J. LINCOLN
K. VICKERMAN
R. M. CONNAN
S. H. P. MADRELL
P. J. WHITFIELD
R. R. A. COOMBS, F.R.S.
M. C. NESHEIM
H. H. WILLIAMS
G. A. M. CROSS
BRIDGET M. OGILVIE
C. A. WRIGHT
D. A. ERASMUS
W. PETERS

VOLUME 69, 1974

\section{CAMBRIDGE}

AT THE UNIVERSITY PRESS

1974 


\section{PUBLISHED BY}

THE SYNDICS OF THE UNIVERSITY PRESS

Bentley House, 200 Euston Road, London NW1 2DB

American Branch: 32 East 57th Street, New York, N.Y.10022

(C) Cambridge University Press, 1974 


\section{CONTENTS}

\section{Part 1 August 1974}

Long, P. L., Fernando, M. A. and Remmler, O. Experimental infections of the domestic fowl with a variant of Eimeria praecax from the Ceylon jungle fowl .

Betterton, Christine. Studies on the host specificity of the eyefluke, Diplostomum spathaceum, in brown and rainbow trout

Duffus, W. P. H. and Wagner, G. G. The specific immunoglobulin response in cattle immunized with Theileria parva (Muguga) stabilate .

Wagner, G. G., Duffus, W.P. H. and Burridge, M. J. The specific immunoglobulin response in cattle immunized with isolated Theileria parva antigens

De Nolits, Sonja, Borgers, M., Vanpariss, O. and van den Bossche, $H$. Effects of mebendazole on the encysted phase of Trichinella spiralis in the rat: an electron microscope study .

Hopkins, C. A. and STALlaRd, H. E. Immunity to intestinal tapeworms: the rejection of Hymenolepis citelli by mice . . . . . . .

Befus, A. D. and Featherston, D.W. Delayed rejection of single Hymenolopis diminuta in primary infections of young mice

Norton, C. C., Joyner, L. P. and Catchpole, JAnet. Eimeria weybridgensis sp.nov. and Eimeria ovina from the domestic sheep . .

Bryant, Victoria. Growth and respiration throughout the life-cycle of Nematospiroides dubius Baylis (1926) (Nematoda: Heligmosomidae): the parasitic stage

\section{Part 2 OCtober 1974}

Kim, Ke Chung and Weisser, Christian F. Taxonomy of Solenopotes Enderlein, 1904, with redescription of Linoganthus panamensis Ewing (Linognathidae: Anoplura)

Reader, Trevor A. J. Histochemical observations on the distribution of various oxidative and phosphorylative enzymes in larval digeneans parasitizing Bithynia tentaculata (Mollusca: Gastropoda)

Halvorsen, Odd and Andersen, Karin. Some effects of population density in infections with Diphyllobothrium dendriticum (Nitzsch) in golden hamster (Mesocricetus auratus Waterhouse) and common gull (Larus canus L.) 
Armour, J. and Bruce, R. G. Inhibited development of Ostertagia ostertagi infections - a diapause phenomenon in a nematode.

WARD, P. F. V. The metabolism of glucose by Haemonchus contortus, in vitro

Turton, J. A. and Clark, C. J. The effect of natural worm loss on the estimate of anthelmintic activity in an anthelmintic test with Haemonchus contortus .

Cannon, L. R. G. and Rzepczyk, C. M. A new species of Caryospora Léger, 1904 (Sporozoa: Eimeriidae) from an Australian snake

ARMe, C. and Fox, M. G. Oxygen uptake by Diclidophora merlangi (Monogenea).

Phillipson, R. F. Intermittent egg release by Aspiculuris tetraptera in mice

Larnson, R., Landad, Irìne and Shaw, J. J. Observations on nonpigmented haemosporidia of Brazilian lizards including a new species of Saurocytozoon in Mabuya mabouya (Scincidae)

Krllick-KendRICK, R. Parasitic protozoa of the blood of rodents: a revision of Plasmodium berghei

Dobson, Colin and Bawden, Richard J. Studies on the immunity of sheep to Oesophagostomum columbianum: effects of low-protein diet on resistance to infection and cellular reactions in the gut

Kearn, Graham C. A comparative study of the glandular and excretory systems of the oncomiracidia of the monogenean skin parasites Entobdella hippoglossi, E. diadema and E. soleae

Proceedings of the British Society for Parasitology, 2-4 April 1974

\section{Part 3 December}

Allsopr, B. A. and NJogu, A. R. Monosaccharide composition of the surface glycoprotein antigens of Trypanosoma brucei

Chapman, H. D. Use of chick embryo infections for the study of drug

Sweetrag, R. A. Investigations into natural and experimental infections of freshwater fish by the common eye-fluke Diplostomum spathaceum Rud.

Chiejina, S. N. and Sewell, M. M. H. Experimental infections with Trichostrongylus colubriformis (Giles, 1892) Loos, 1905 in lambs: worm burden, growth rate and host resistance resulting from prolonged escalating infections . 
ChIEjINa, S. N. and Seweld, M. M. H. Worm burdens, acquired resistance and live weight gains in lambs during prolonged daily infections with Trichostrongylus colubriformis (Giles, 1892) Loos, 1905 . . . .

Neame, K. D., Brownbill, P. A. and Homewood, C. A. The uptake and incorporation of nucleosides into normal erythrocytes and erythrocytes

Long, P. L. Experimental infection of chickens with two species of Eimeria isolated from the Malaysian jungle fowl

Perez, Hitda, Clegg, J. A. and Smithers, S. R. Acquired immunity to Schistosoma mansoni in the rat: measurement of immunity by the lung recovery technique.

Boxshall, G. A. The population dynamics of Lepeophtheirus pectoralis (Müller): seasonal variation in abundance and age structure .

Boxshall, G. A. The population dynamics of Lepeophtheirus pectoralis (Müller): dispersion pattern

BenNke, JeRzy M. The distribution of larval Aspiculuris tetraptera Schulz during a primary infection in Mus musculus, Rattus norvegicus and Apodemus sylvaticus

Ghazal, A. M. and Avery, R. A. Population dynamics of Hymenolepis nana in mice: fecundity and the 'crowding effect'.

Lewis, J. W., Jones, D. R. and Apams, J. R. Functional bursting by the dranunculoid nematode, Philonema oncorhynchi . . . . .

Crompton, D. W. T. and Whitfield, P.J. Observations on the functional organization of the ovarian balls of Moniliformis and Polymorphus (Acanthocephala) . . . . . . . . . .

Zamirdin, Mohamed and Wilson, Peter, A. G. Strongyloides ratti: relative importance of maternal sources of infection . . . .

Austin, F., Frappaolo, P., Gilbert, B., Landis, W., da Rosa, M. N. and STIREwalt, M. Further studies of Schistosoma mansoni cercarial stimulation by crude egg lecithin and other lipids . 


\section{PARASITOLOGY}

SU B SCRIPTIONS may be sent to any bookseller or subscription agent or direct to Cambridge University Press, P.O. Box 92, London NW1 2DB. Subscriptions in the U.S.A. and Canada should be sent to Cambridge University Press, 32 East 57th Street, New York, N.Y. 10022. The 1974 subscription price is $£ 11.00$ net (including postage) for a volume of three parts (US $\$ 35.00$ in the U.S.A. and Canada), payable in advance ( $\$ 22.00$ or US $\$ 70.00$ per year); separate parts eost $£ 5.00$ net or US $\$ 15.00$ each (plus postage).

B ACK volumes. Vols. 1-39: Inquiries should be addressed to Wm Dawson \& Sons Ltd, Cannon House, Folkestone, Kent. Vols. 40 onwards: Quotations for parts still in print may be obtained from the London or New York offices of the Cambridge University Press.

FOR PERMISSION to reproduce material from Parasitolony, please apply to the London or New York office of Cambridge University Press.

is i tear Service, 325 Chestnut Street, Philadelphia, Pennsylvania 19106, U.S.A. is authorized to supply single copies of separate articles for private use only.

CLAIMS for missing issues can only be considered if made immediately after receipt of the subsequent issue.

ADVERTISING. Details of advertising in Parasitology may be obtained from the publisher. 


\section{PARASITOLOGY}

Volume 69, Part 3, December 1974

\section{GONTENTS}

Ancsopp, B. A. and NJogu, A. R. Monosaccharide composition of the surface glycoprotein antigens of Trypanosoma brucei

PAGE

Chapman, H. D. Use of ehick embryo infections for the study of drug resistance in Eimeria tenella

SweEting, R. A. Investigations into natural and experimental infections of freshwater fish by the common eye-fluke Diplostomum spathaceum Rud.

ChIEJINa, S. N. and Sewell, M. M. H. Experimental infections with Trichostrongylus colubriformis (Giles, 1892) Loos, 1905 in lambs: worm burden, growth rate and host resistance resulting from prolonged escalating infections

Chinjna, S. N. and Sewell, M. M. H. Worm burdens, acquired resistance and live weight gains in lambs during prolonged daily infections with Trichostrongylus colubriformis (Giles, 1892) Loos 1905

Neame, K. D., Brownbmi, P. A. and Homewood, C. A. The uptake and incorporation of nucleosides into normal erythrocytes and erythrocytes eontaining Plasmodium berghei

LoNG, P. L. Experimental infection of chickens with two species of Eimeria isolated from the Malaysian jungle fowl

Perez, Hilda, Clegg, J. A. and Smithers, S. R. Acquired immunity to Schistosoma manson $i$ in the rat: measurement of immunity by the lung recovery technique

Boxshall, G. A. The population dynamies of Lepeophtheirus pectoralis (Müller): seasonal variation in abundance and age strueture

Boxshant, G.A. The population dynamics of Lepeophtheirus pectoralis (Müller): dispersion pattern

BeHNke, Jerzy M. The distribution of larval Aspiculuris tetraptera Schulz during a primary infection in Mus musculus, Rattus norvegicus and Apodemus sylvaticus

Ghazal, A. M. and Avery, R. A. Population dynamies of Hymenolepis nana in mice: fecundity and the 'crowding effect'

Lewrs, J. W., Jones, D. R. and ADAMs, J. R. Functional bursting by the dranunculoid nematode Philonema oncorhynchi

Crompton, D. W. T. and Whtrfield, P. J. Observations on the functional organization of the ovarian balls of Moniliformis and Polymorphus (Acanthocephala)

Zamirdin, Mohamed and Wilson, Peter A. G. Strongyloides ratti: relative importance of maternal sources of infection

Austin, F., Frappaolo, P., Gilbert, B., Landis, W., da Rosa, M. N. and Strrewalt, M. Further studies of Schistosoma mansoni cercarial stimulation by erude egg lecithin and other lipids

(C) Cambridge University Press 1974

Bentley House, 200 Euston Road, London NW1 2DB

American Branch: 32 East 57th Street, New York, N.Y. 10022

Printed in Great Britain at the University Printing House, Cambridge 